\title{
The invasive weed, Asystasia gangetica as a biomonitor of heavy metal bioavailability and pollution
}

\begin{abstract}
In this study, the weed Asystasia gangetica and surface soils were collected from six sampling sites in Peninsular Malaysia, including two landfill sites (Matang and Sg. Kembung), one industrial site (Juru) and three residential sites (Bukit Rasa, Ijok and Pagoh). The plants were separated into roots, stems and leaves. The ranges of metal concentrations ( $\varepsilon \mathrm{g} / \mathrm{g}$ dry weight) in these pooled roots, stems and leaves were $0.03 \mathrm{i} 1.01,0.03 \mathrm{i} 0.66$ and 0.03 ï 0.94, respectively for $\mathrm{Cd}$; 12.11 ï 27.9, 6.76ї 10.0, 9.92ï 19.8, respectively for $\mathrm{Cu} ; 201.9 \ddot{\mathrm{I}}$ 929, $27.8 і ̈ 579$ and 87.1ї 1299, respectively for Fe; $1.01 \ddot{3} 3.36,0.64 і ̈ 2.20$ and $0.10 і ̈$ 4.95, respectively for $\mathrm{Ni}$; $4.58 \mathrm{ï} 8.28,1.76 \mathrm{ï} 7.79$ and $2.10 \mathrm{ï} 21.79$, respectively for $\mathrm{Pb}$; and $66.0 \mathrm{ï} 161$, 52.6ї 148 and 35.7ï 159, respectively for $\mathrm{Zn}$. Elevated metal levels were found in the industrial site at Juru and the landfill site at Sg. Kembung in A. gangetica, indicating high bioavailabilities to the weed. The accumulation patterns were Root $>$ Stem $>$ Leaf for $\mathrm{Zn}$, Root $>$ Leaf $>$ Stem for Fe, $\mathrm{Cu}$ and $\mathrm{Cd}$, and Leaf $>$ Root $>$ Stem for Ni and Pb. Based on the metal levels and clustering patterns, the different weed parts were shown to be potential biomonitors of heavy metal pollution. The Juru site was evidently found to be the highly metal-contaminated and had highest bioavailability of heavy metals. The Sg. Kembung site was found as the most metal-polluted site in which the levels of $\mathrm{Cd}, \mathrm{Cu}, \mathrm{Ni}, \mathrm{Pb}$ and $\mathrm{Zn}$ in the soils exceeded the soil quality guidelines. The different weed parts could be used as biomonitors of heavy metal bioavailabilities and contamination of the sampling sites; in particular, the stem of the plant was a good biomonitor for $\mathrm{Cu}$ pollution.
\end{abstract}

Keyword: Biomonitor; Heavy metals; Different parts; Soils 